\title{
Renal function and insulin resistance as determinants of plasma leptin levels in patients with NIDDM
}

\author{
T. Shoji, Y. N ishizawa, M. E moto, K. M aekawa, Y. H iura, S. Tanaka, T. K awagishi, Y. O kuno, H . M orii \\ Second Department of Internal Medicine, Osaka City University Medical School, Japan
}

Summary Plasma leptin level is known to correlate with the degree of obesity. To determine the influences of renal fuction and insulin resistance on plasma leptin concentrations, we measured plasma leptin concentrations and performed the euglycaemic hyperinsulinaemic clamp studies in 57 patients with non-insulin-dependent diabetes mellitus with a wide range of renal function. In simple regression analyses, plasma leptin concentration showed significant positive correlations with percentage of body fat measured by dual energy X-ray absorptiometry, body mass index, waist to hip ratio and fasting plasma insulin. Leptin level was higher in females than males.
Multiple regression analyses indicated that percent body fat, waist to hip ratio, plasma insulin, gender and renal function (1/creatinine), but not insulin sensitivity, were significant and independent determinants of plasma leptin level. These results suggest that plasma leptin level is regulated or affected by multiple factors including renal function. Insulin resistance appeared to increase leptin levels indirectly by raising plasma insulin. [Diabetologia (1997) 40: 676-679]

Keywords Leptin, insulin, body fat, non-insulin-dependent diabetes mellitus, renal function.
Leptin is a newly found hormone secreted by adipocytes [1]. It is the ob gene product which regulates food intake and thermogenesis [2-4]. The ob/ob mouse has a mutation in the ob gene [1], and $\mathrm{db} / \mathrm{db}$ mice have a mutation in the gene coding for the leptin receptor $[5,6]$. Therefore, leptin could play an important role in the pathogenesis of obesity and diabetes mellitus. In humans, however, the majority of obese subjects have elevated plasma leptin concentrations [7-9], suggesting the presence of leptin resistance [10]. The mechanisms regulating plasma leptin level or leptin resistance are not fully understood. Body fatness was one of the important determinants of

Received: 27 November 1996 and in revised form: 3 March 1997

Corresponding author: Y. Nishizawa, M.D., Second Department of Internal Medicine, Osaka City University Medical School, 1-5-7, Asahi-machi, Abeno-ku, Osaka 545, Japan A bbreviations: NIDDM, Non-insulin-dependent diabetes mellitus; WHR, waist to hip ratio. plasma leptin levels [7-9]. Some studies showed that insulin infusion increased plasma leptin concentration $[11,12]$, although other studies [13] did not. One report [13] indicated that insulin resistance was associated with elevated plasma leptin concentrations independent of body fat, whereas more recent studies $[14,15]$ failed to detect the independent contribution of insulin sensitivity or body fat distribution, an indicator of insulin resistance [16], to plasma leptin concentration. In addition, there is a possibility that renal function may play an important role in the regulation of plasma leptin concentration. Renal impairment results in insulin resistance and hyperinsulinaemia [17]. Also, the kidney is among the organs expressing leptin receptors [18], although their functions are unknown at present. To answer these controversies and to evaluate the possible impact of renal function on leptin, we performed the euglycaemic hyperinsulinaemic clamp in 57 patients with non-insulin-dependent diabetes mellitus (NIDDM). The results suggest that: 1) both total mass and distribution of body fat are important determinants of leptin levels; 2) leptin 
Table 1. Clinical characteristics of the subjects and their correlation with plasma leptin levels

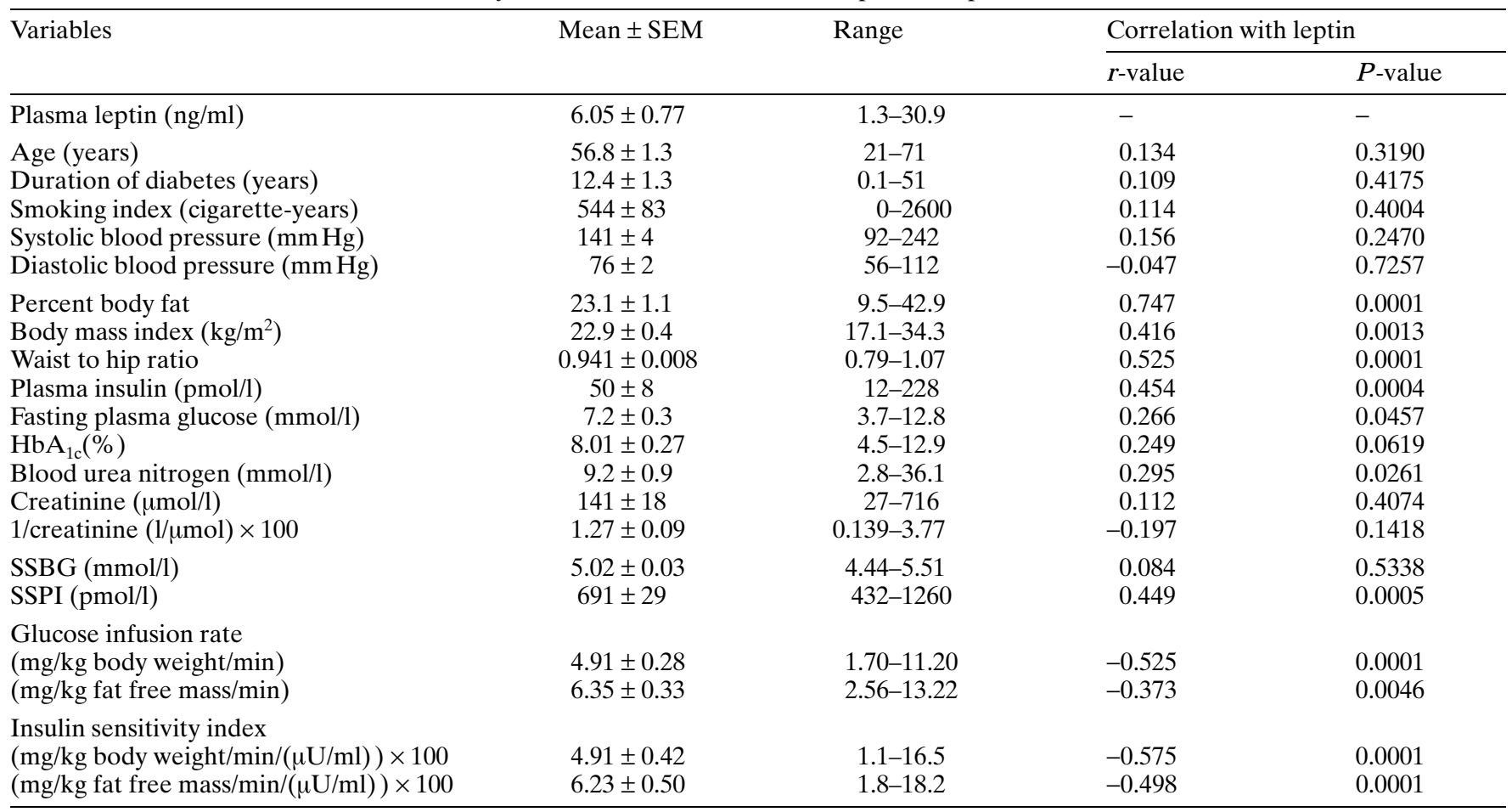

Leptin level was log-transformed before correlation analysis. SSBG, steady state blood glucose; SSPI, steady state plasma insulin. Glucose infusion rate and insulin sensitivity index were expressed on the basis of both body weight and fat free mass

level is associated more closely with plasma insulin level than with insulin sensitivity itself; and 3) impaired renal function is another independent factor affecting plasma leptin concentrations.

\section{Subjects and methods}

Subjects. Fifty-seven patients with NIDDM (36 males and 21 females) were studied. Eleven patients were treated with diet only, 22 with sulfonylurea, and 24 with insulin. Regarding nephropathy stages [19], 20, 13, 9 and 15 patients had nephropathy stages I (urinary albumin excretion, UAE $<30 \mathrm{mg} / 24 \mathrm{~h}$ ), II (UAE, 30-300 mg/24 h), III (UAE > $300 \mathrm{mg} / 24 \mathrm{~h}$ ) and IV (plasma creatinine $>180 \mu \mathrm{mol} / \mathrm{l}$ ), respectively. Other clinical characteristics are given in Table 1.

Plasma leptin concentration. Plasma leptin concentration was measured by radio- immunoassay using commercial kits $(\mathrm{Hu}-$ man Leptin RIA kit; Linco Research Inc., St. Charles, Mo., USA). The sensitivity of the assay was $0.5 \mathrm{ng} / \mathrm{ml}$.

Clamp study. Euglycaemic hyperinsulinaemic clamp was performed according to DeFronzo et al. [20] using an artificial pancreas model STG 22 (Nikkiso Co., Tokyo, Japan) as previously described [21]. Clamp studies and blood samplings were done after an overnight fast. Evening dose of insulin was discontinued prior to the study. Insulin (Humulin R, Eli Lilly \& Company, Indianapolis, Ind., USA) was infused in a primed continuous manner at a rate of $1.25 \mathrm{mU} \cdot \mathrm{kg}^{-1} \cdot \mathrm{min}^{-1}$. The steady state blood glucose level of $5 \mathrm{mmol} / \mathrm{l}$ was maintained by adjusting the infusion rate of $20 \%$ glucose solution. Blood glucose was monitored at 5-min intervals during the 120 -min clamp study. Insulin sensitivity index was defined as glucose infusion rate per body weight or per fat free mass corrected against the steady state plasma insulin level during the last 30 min of the clamps.

Body fat measurement. Body fat mass was measured by dual energy X-ray absorptiometry (model QDR-2000; Hologic, Waltham, Mass., USA), and expressed as percent body fat. Body fat distribution was assessed by waist to hip ratio (WHR).

O ther measurements. Glucose was measured by the glucose oxidase method, haemoglobin $\mathrm{A}_{1 \mathrm{c}}$ by high pressure liquid chromatography, and plasma insulin by radioimmunometric assay (Insulin RIABEAD II; Dinabot Co., Tokyo, Japan). Other measurements were by routine clinical methods.

Statistical analysis. Results are expressed as mean \pm SEM. Differences of mean values between two groups were evaluated by Student's t-test and difference of medians was assessed by Mann-Whitney's U-test. Correlation between two variables was examined by simple regression analysis. Independent associations between one dependent variable and more than two independent variables were assessed by multiple regression analyses. $\mathrm{P}$-values less than 0.05 were taken to be statistically significant. Plasma leptin levels were log-transformed before simple and multiple regression analyses, because its distribution was not normal. 
Table 2. Multiple regression analysis of factors affecting plasma leptin levels

\begin{tabular}{|c|c|c|c|c|c|c|c|}
\hline Independent & Model-1 & Model-2 & Model-3 & Model-4 & Model-5 & Model-6 & Model-7 \\
\hline Percent body fat & $0.747^{\mathrm{a}}$ & $0.655^{\mathrm{a}}$ & $0.435^{\mathrm{a}}$ & $0.380^{\mathrm{a}}$ & $0.408^{\mathrm{a}}$ & $0.405^{\mathrm{a}}$ & $0.429^{\mathrm{a}}$ \\
\hline Waist to hip ratio & & $0.313^{\mathrm{a}}$ & $0.401^{\mathrm{a}}$ & $0.333^{\mathrm{a}}$ & $0.279^{a}$ & $0.215^{\mathrm{b}}$ & $0.231^{\mathrm{b}}$ \\
\hline Gender & & & $-0.319^{\mathrm{b}}$ & $-0.297^{\mathrm{b}}$ & $-0.366^{\mathrm{a}}$ & $-0.317^{\mathrm{a}}$ & $-0.386^{\mathrm{a}}$ \\
\hline 1/creatinine & & & & & $-0.259^{a}$ & $-0.263^{\mathrm{a}}$ & $-0.282^{\mathrm{a}}$ \\
\hline Basal insulin level & & & & & & $0.198^{\mathrm{b}}$ & $0.225^{\mathrm{b}}$ \\
\hline $\mathrm{R}^{2}$ & $0.558^{\mathrm{a}}$ & $0.656^{\mathrm{a}}$ & $0.713^{\mathrm{a}}$ & $0.749^{\mathrm{a}}$ & $0.803^{\mathrm{a}}$ & $0.832^{\mathrm{a}}$ & $0.825^{\mathrm{a}}$ \\
\hline
\end{tabular}

Standard regression coefficients $(\beta)$ were given with the level of significance. ${ }^{\mathrm{a}} \mathrm{p}<0.001 ;{ }^{\mathrm{b}} p<0.01 ;{ }^{\mathrm{c}} p<0.05$. NS, Not significant. $R^{2}$, multiple coefficient of determination. Dummy variables were used for gender (female $=1$, male $=2$ ). Insulin sen- sitivity indicates that of body weight basis. When the fat free mass-based insulin sensitivity was entered in the models, essentially the same results were obtained

\section{Results}

Plasma leptin level in the 57 NIDDM patients was $6.1 \pm 0.8 \mathrm{ng} / \mathrm{ml}$ (mean \pm SEM). Female patients had significantly higher leptin concentrations than male patients $(3.9 \pm 0.6$ vs $9.7 \pm 1.5 \mathrm{ng} / \mathrm{ml}, \mathrm{P}=0.0001$ by Student's t-test or by Mann-Whitney's U -test).

Table 1 shows results of simple regression analyses between leptin and other variables. Plasma leptin level correlated positively with percentage body fat, BMI, WHR and fasting insulin, whereas it correlated inversely with insulin sensitivity index. No significant correlation was found between leptin and renal function by simple regression analyses.

Table 2 summarizes multiple regression analyses of factors independently affecting plasma leptin levels. The model-1 through model-3 indicated percentage body fat, WHR, and gender were all significant and independent determinants of plasma leptin levels. When insulin sensitivity and renal function were included as the 4th and 5th variables, respectively, the association between leptin and these variables appeared to be significant (model-4 and 5). However, in the model in which plasma insulin level was considered (model-6), the association between insulin sensitivity and leptin disappeared whereas the impact of insulin level on leptin became significant. In this model, the inverse association between renal function and leptin levels remained significant, indicating the association was independent of insulin sensitivity and fasting plasma insulin level. Finally, more than $82 \%$ of the variation in plasma leptin concentration was explained by five variables including total body fat mass, fat distribution, insulin level, gender and renal function (model-7).

\section{Discussion}

Plasma leptin levels correlate with body fat mass [79]. Leptin level may be influenced by other factors including renal function and insulin resistance [13-15]. Results of the present study indicated renal function as an important determinant of plasma leptin levels. Insulin resistance appeared to contribute to hyperleptinaemia by raising plasma insulin levels.

It is a novel finding that renal function was significantly associated with plasma leptin levels. We had anticipated this because renal failure results in insulin resistance and hyperinsulinaemia [17]. However, the association between renal function and plasma leptin level was independent of plasma insulin and insulin resistance. Therefore, other explanations are needed. The leptin receptors have a wide distribution among organs including the central nervous system and the kidney [18], suggesting that the kidney may play a role in the clearance of plasma leptin. According to a preliminary report by Coyne et al.[22], plasma leptin level in haemodialysis patients is elevated and not because of accumulation of leptin degradation products. They did not address the possible effect of hyperinsulinaemia on leptin. We demonstrated that elevation in plasma leptin due to impaired renal function occurred independently of other metabolic and endocrinological factors. The kidney may play a physiological role in leptin clearance [23]. If the intact leptin molecules are accumulated due to renal failure, hyperleptinaemia might account, at least in part, for malnutrition of patients with chronic renal failure.

The effects of insulin on plasma leptin level are controversial. Exogenously administered insulin increases the ob-gene expression and secretion of leptin in rodents [24]. In humans, insulin infusion for $3 \mathrm{~h}$ was reported not to increase plasma leptin levels [13]. Other studies $[11,12]$ reported an increased plasma leptin level after a 6-8 h hyperinsulinaemic clamp. In the present study, we revealed the significant impact of fasting plasma insulin concentration on plasma leptin levels in patients with NIDDM. Taken together, these studies suggest that plasma leptin level in humans is regulated by insulin not in an acute but in a chronic manner.

It has not been established whether insulin resistance affects plasma leptin levels independently. Segal et al. [13] showed that insulin-resistant lean men had higher plasma leptin levels than insulin-sensitive 
lean men, and concluded that insulin resistance is associated with elevated leptin level independently of body fat. In that study, however, a higher plasma insulin level in the insulin resistant men was not taken into account. In contrast, Dua et al. [14] and Larsson et al. [15] failed to detect a significant relationship between plasma leptin concentration and insulin-sensitivity assessed by Bergman's minimal model [14] or by euglycaemic hyperinsulinaemic clamp technique [15]. Simple regression analysis in our study showed a significant inverse correlation between plasma leptin level and insulin sensitivity index by the euglycaemic hyperinsulinaemic clamp technique. However, multiple regression analyses did not indicate insulin sensitivity as a significant independent factor for plasma leptin concentrations when plasma insulin level was included in the analysis. Although these results could not deny the independent effect of insulin resistance on hyperleptinaemia, we interpret the data to indicate that insulin resistance indirectly contributes to hyperleptinaemia by raising plasma insulin levels.

In conclusion, our results suggested that plasma leptin level was regulated or affected by multiple factors including renal function. Insulin resistance appeared to affect plasma leptin level via hyperinsulinaemia, although insulin sensitivity itself was not shown to be an independent determinant of leptin. Further studies are needed to clarify the precise mechanisms for these correlations, especially the relationship between renal function and leptin, to better understand obesity, malnutrition and related metabolic disorders.

\section{References}

1. Zhang Y, Proenca R, Maffei M, Barone M, Leopold L, Friedman J (1994) Positional cloning of the mouse obese gene and its human homologue. Nature 372: 425-432

2. Pelleymounter MA, Cullen MJ, Baker MB et al. (1995) Effects of the obese gene product on body weight regulation in ob/ob mice. Science 269: 540-543

3. Halaas JL, Gajiwala KS, Maffei M et al. (1995) Weight reducing effects of the plasma protein encoded by the obese gene. Science 269: 543-546

4. Campfield LA, Smith FJ, Guizez Y, Devos R, Burn P (1995) Recombinant mouse OB protein: evidence for a peripheral signal linking adiposity and central neural networks. Science 269: 546-549

5. Chen H, Charlat O, Tartaglia LA et al. (1996) Evidence that the diabetes gene encodes the leptin receptor: identification of a mutation in the leptin receptor gene in $\mathrm{db} / \mathrm{db}$ mice. Cell 84: 491-495

6. Lee GH, Proenca R, Montez JM et al. (1996) Abnormal splicing of the leptin receptor in diabetic mice. Nature 379: 632-635
7. Lonnquist F, Arner P, Nordford L, Schalling M (1995) Overexpression of the obese $(\mathrm{Ob})$ gene in adipose tissue of human obese subjects. Nature Med 1: 950-953

8. Hamilton BS, Paglia D, Kwan AYM, Deitel M (1995) Increased obese mRNA expression in omental fat cells from massively obese humans. Nature Med 1: 953-956

9. Considine RV, Sinha MK, Heiman ML et al. (1995) Serum immunoreactive-leptin concentrations in normal-weight and obese humans. N Engl J Med 334: 292-295

10. Caro JF, Sinha MK, Kolaczynski JW, Zhang PL, Considine RV (1996) Leptin: the tale of an obesity gene. Diabetes 45: $1455-1462$

11. Malmstrom R, Taskinen M-R, Karonen S-L, Yki-Jarvinen $H$ (1996) Insulin increases plasma leptin concentrations in normal subjects and patients with NIDDM. Diabetologia 39: 993-993

12. Kolaczynski JW, Nyce MR, Concidine RV et al. (1996) Acute and chronic effect of insulin on leptin production in humans. Studies in vivo and in vitro. Diabetes 45: 699-701

13. Segal KR, Landt M, Klein S (1996) Relationship between insulin sensitivity and plasma leptin concentration in lean and obese men. Diabetes 45: 988-991

14. Dua A, Hennes MI, Hoffmann RG, Maas DL, Krakower GR, Sonnenberg GE, Kissebah AH (1996) Leptin: a significant indicator of total body fat but not of visceral fat and insulin insensitivity in African-American women. Diabetes 45: $1635-1637$

15. Larsson H, Elmstahl S, Ahren B (1996) Plasma leptin levels correlate to islet function independently of body fat in postmenopausal women. Diabetes 45: 1580-1584

16. Kissebah A, Vydelingum N, Murray R, Evans D, Hartz A, Kalkhoff RK, Adams PW (1982) Relation of body fat distribution to metabolic complications of obesity. J Clin Endocrinol Metab 54: 254-260

17. DeFronzo RA, Alvestrand A, Smith D, Hendler R, Hendler E, Wahren J (1981) Insulin resistance in uremia. J Clin Invest 67: 563-568

18. Tartaglia LA, Dembski M, Weng X et al. (1995) Identification and expression cloning of a leptin receptor, OB-R. Cell 83: $1263-1271$

19. ADA consensus statement (1996) Diagnosis and management of nephropathy in patients with diabetes mellitus. Diabetes Care 19: S103-S106

20. DeFronzo RA, Tobin JD, Andres R (1979) Glucose clamp technique: a method for quantifying insulin secretion and resistance. Am J Physiol 237:E214-E223

21. Ishimura E, Nishizawa Y, Emoto M, Maekawa K, Morii H (1996) Effect of insulin on urinary phosphate excretion in type II diabetes mellitus with or without renal insufficiency. Metabolism 45: 782-786

22. Coyne DW, Marabet E, Dagogo-Jack S, Klein S, Santiago JV, Hmiel SP, Landt M (1996) Increased leptin concentrations in hemodialysis (HD) patients. J Am Soc Nephrol 7: 1630 (Abstract)

23. Sharma K, Michael B, Dunn S et al. (1996) Plasma leptin is cleared by the kidney and is markedly elevated in hemodialysis patients. J Am Soc Nephrol 7: 1864 (Abstract)

24. Saladin R, De Vos P, Guerre-Millo M, Leturque A, Girard J, Staels B, Auwerx J (1995) Transient increase in obese gene expression after food intake or insulin administration. Nature 377: 527-529 